\title{
Atmospheric OH reactivity in central London: observations, model predictions and estimates of in situ ozone production
}

\author{
Lisa K. Whalley ${ }^{1,2}$, Daniel Stone ${ }^{1}$, Brian Bandy ${ }^{3}$, Rachel Dunmore ${ }^{4}$, Jacqueline F. Hamilton ${ }^{4}$, James Hopkins ${ }^{4,5}$, \\ James D. Lee ${ }^{4,5}$, Alastair C. Lewis ${ }^{4,5}$, and Dwayne E. Heard ${ }^{1,2}$ \\ ${ }^{1}$ School of Chemistry, University of Leeds, Leeds, LS2 9JT, UK \\ ${ }^{2}$ National Centre for Atmospheric Science, University of Leeds, Leeds, LS2 9JT, UK \\ ${ }^{3}$ School of Environmental Sciences, University of East Anglia, Norwich Research Park, Norwich, NR4 7TJ, UK \\ ${ }^{4}$ Wolfson Atmospheric Chemistry Laboratories, Department of Chemistry, University of York, Heslington, York, \\ YO10 5DD, UK \\ ${ }^{5}$ National Centre for Atmospheric Science, University of York, Heslington, York, YO10 5DD, UK \\ Correspondence to: Lisa K. Whalley (1.k.whalley@leeds.ac.uk)
}

Received: 27 October 2015 - Published in Atmos. Chem. Phys. Discuss.: 9 November 2015

Revised: 8 February 2016 - Accepted: 11 February 2016 - Published: 24 February 2016

\begin{abstract}
Near-continuous measurements of hydroxyl radical $(\mathrm{OH})$ reactivity in the urban background atmosphere of central London during the summer of 2012 are presented. $\mathrm{OH}$ reactivity behaviour is seen to be broadly dependent on air mass origin, with the highest reactivity and the most pronounced diurnal profile observed when air had passed over central London to the east, prior to measurement. Averaged over the entire observation period of 26 days, $\mathrm{OH}$ reactivity peaked at $\sim 27 \mathrm{~s}^{-1}$ in the morning, with a minimum of $\sim 15 \mathrm{~s}^{-1}$ during the afternoon. A maximum $\mathrm{OH}$ reactivity of $116 \mathrm{~s}^{-1}$ was recorded on one day during morning rush hour. A detailed box model using the Master Chemical Mechanism was used to calculate $\mathrm{OH}$ reactivity, and was constrained with an extended measurement data set of volatile organic compounds (VOCs) derived from a gas chromatography flame ionisation detector (GC-FID) and a twodimensional GC instrument which included heavier molecular weight (up to $\mathrm{C}_{12}$ ) aliphatic VOCs, oxygenated VOCs and the biogenic VOCs $\alpha$-pinene and limonene. Comparison was made between observed $\mathrm{OH}$ reactivity and modelled $\mathrm{OH}$ reactivity using (i) a standard suite of VOC measurements $\left(\mathrm{C}_{2}-\mathrm{C}_{8}\right.$ hydrocarbons and a small selection of oxygenated VOCs) and (ii) a more comprehensive inventory including species up to $\mathrm{C}_{12}$. Modelled reactivities were lower than those measured (by $33 \%$ ) when only the reactivity of the standard VOC suite was considered. The difference between measured and modelled reactivity was improved, to
\end{abstract}

within $15 \%$, if the reactivity of the higher VOCs $\left(\geqslant \mathrm{C}_{9}\right)$ was also considered, with the reactivity of the biogenic compounds of $\alpha$-pinene and limonene and their oxidation products almost entirely responsible for this improvement. Further improvements in the model's ability to reproduce $\mathrm{OH}$ reactivity (to within $6 \%$ ) could be achieved if the reactivity and degradation mechanism of unassigned two-dimensional GC peaks were estimated. Neglecting the contribution of the higher VOCs $\left(\geqslant \mathrm{C}_{9}\right)$ (particularly $\alpha$-pinene and limonene) and model-generated intermediates increases the modelled $\mathrm{OH}$ concentrations by $41 \%$, and the magnitude of in situ ozone production calculated from the production of $\mathrm{RO}_{2}$ was significantly lower $(60 \%)$. This work highlights that any future ozone abatement strategies should consider the role that biogenic emissions play alongside anthropogenic emissions in influencing London's air quality.

\section{Introduction}

It has been estimated that there may be in excess of $10^{5}$ different VOC species present in the atmosphere globally (Goldstein and Galbally, 2007) and it is the hydroxyl radical $(\mathrm{OH})$ which is primarily responsible for the processing and eventual removal of these compounds. In an urban setting, rich with vehicular emissions, the task of accurately quantifying the total rate of reactive $\mathrm{OH}$ loss using measurements 
of each individual VOC present is unfeasible. Yet underestimations of the loss rate of $\mathrm{OH}$ can lead to inaccuracies in predicting the $\mathrm{OH}$ concentration and oxidation capacity and, in $\mathrm{NO}_{x}$-rich areas, such as urban centres, ozone production resulting from the reaction between peroxy radicals (formed during $\mathrm{OH}$ oxidation of VOCs and $\mathrm{CO}$ ) and $\mathrm{NO}$ may be underestimated.

It is possible to measure the total $\mathrm{OH}$ reactivity, defined as

$k_{\mathrm{OH}}=\sum_{i} k_{\mathrm{OH}+X_{i}}\left[X_{i}\right]$,

where $\left[X_{i}\right]$ represents the concentration of species which react with $\mathrm{OH}\left(\mathrm{VOC}, \mathrm{NO}_{2}, \mathrm{CO}\right.$ etc.) and $k_{\mathrm{OH}+X_{i}}$ is the corresponding bimolecular rate constant.

The techniques used to determine $k_{\mathrm{OH}}$ include the flow tube with sliding injector method pioneered by Brune and co-workers (Kovacs and Brune, 2001), a comparative rate method (Sinha et al., 2008) and a laser flash photolysis pumpprobe technique (Sadanaga et al., 2004). These techniques have been used in a variety of environments and the reader is referred to the overview of previous measurements provided by Lou et al. (2010). Both the flow tube with sliding injector and comparative rate method rely on $\mathrm{H}_{2} \mathrm{O}$ vapour photolysis at $185 \mathrm{~nm}$ using a lamp which generates $\mathrm{OH}$ and $\mathrm{HO}_{2}$ simultaneously. As a consequence, corrections must be made when ambient NO concentrations reach $\sim 1 \mathrm{ppbV}$ or more to account for $\mathrm{OH}$ recycled by reaction of this generated $\mathrm{HO}_{2}$ with NO. The recycled $\mathrm{OH}$, if left uncorrected, effectively slows the rate of the first-order decay of OH (Ingham et al., 2009), leading to an underestimation of the $\mathrm{OH}$ reactivity. Using the flash photolysis technique, $\mathrm{OH}$ is generated by photolysing ozone at $266 \mathrm{~nm}$ followed by reaction of $\mathrm{O}\left({ }^{1} \mathrm{D}\right)$ with $\mathrm{H}_{2} \mathrm{O}$ vapour. $\mathrm{HO}_{2}$ is not formed initially by this method, so it is possible to measure $\mathrm{OH}$ reactivity at significantly higher $\mathrm{NO}$ concentrations before a correction becomes necessary, making this technique well suited to urban measurements of $\mathrm{OH}$ reactivity (Sadanaga et al., 2005).

There have now been several observations of $\mathrm{OH}$ reactivity in urban environments (Kovacs et al., 2003; Ren et al., 2003, 2006; Sadanaga et al., 2005; Shirley et al., 2006; Yoshino et al., 2006; Sinha et al., 2008; Mao et al., 2010; Chatani et al., 2009; Dolgorouky et al., 2012) with some of the highest ever observed values of $>120 \mathrm{~s}^{-1}$ recorded in megacities such as Mexico City (Shirley et al., 2006) and Paris (Dolgorouky et al., 2012). In many cities (Houston, New York City, Mexico City), $\mathrm{OH}$ reactivity has been found to be dominated by anthropogenic hydrocarbons, $\mathrm{CO}$ and $\mathrm{NO}_{x}$. Oxygenated VOCs (OVOCs) have been highlighted as significant $\mathrm{OH}$ sinks in a number of urban studies, contributing between 11 and $24 \%$ during summertime (Mao et al., 2010).

The short-lived $\mathrm{OH}$ radical is in photostationary steady state, with its rates of production, $P_{\mathrm{OH}}$, and destruction, $D_{\mathrm{OH}}$, balanced:

$$
P_{\mathrm{OH}}=D_{\mathrm{OH}}=k_{\mathrm{OH}}[\mathrm{OH}]
$$

and hence simultaneous measurements of $\mathrm{OH}$ reactivity and $\mathrm{OH}$ concentrations permit a field measurement of $P_{\mathrm{OH}}$ and, by comparison with a model constrained using the measured $\mathrm{OH}$ precursors, an assessment of the completeness of the model radical sources can be obtained. This type of $\mathrm{OH}$ budget analysis has proved particularly effective in highlighting large missing $\mathrm{OH}$ sources in low $\mathrm{NO}_{x}$, biogenically influenced regions, such as tropical forests (Whalley et al., 2011). In a number of urban studies conducted in different US cities and Mexico City (Mao et al., 2010), this type of $\mathrm{OH}$ budget analysis has identified that during the morning rush hour, the rate of $\mathrm{OH}$ production exceeds that of destruction $\left(P_{\mathrm{OH}} / D_{\mathrm{OH}}>1\right)$, suggesting uncertainties in either the chemistry used in the model or in the measurements of the precursors of $\mathrm{OH}$ under elevated levels of $\mathrm{NO}_{x}$, which lead to an overestimation of $P_{\mathrm{OH}}$.

$\mathrm{OH}$ reactivity measurements themselves are often compared to calculated values simply using Eq. (1), with $\left[X_{i}\right]$ restricted to those species which are measured in the field, and with knowledge of laboratory kinetic data. In some cases comparison is also made with modelled $\mathrm{OH}$ reactivity, which also includes unmeasured $\mathrm{OH}$ sinks which are often oxygenated VOCs formed following the oxidative degradation of directly emitted hydrocarbon species. Measurements of $\mathrm{OH}$ reactivity are typically higher than those predicted (Lou et al., 2010), with the difference between the measured $\mathrm{OH}$ reactivity and that either calculated or modelled referred to as the missing $\mathrm{OH}$ reactivity. Analysis of the magnitude of this disagreement when calculated and modelled $\mathrm{OH}$ reactivity are used to compare with field determined $k_{\mathrm{OH}}$, enables some distinction to be made between the fraction of missing $\mathrm{OH}$ reactivity due to missing primary emissions and that due to unmeasured oxidised intermediates.

Missing reactivity is often largest in forested environments, (e.g. Edwards et al., 2013), with both missing primary emissions (Di Carlo et al., 2004) and oxidised intermediates (Edwards et al., 2013) considered as potential contributors. In contrast, analysis made during a number of urban studies has demonstrated good agreement between measured $\mathrm{OH}$ reactivity and that calculated using Eq. (1) from individually measured OH sinks (Ren et al., 2003; Di Carlo et al., 2004; Mao et al., 2010). In almost all urban studies to date, the measured $\mathrm{OH}$ reactivity has been compared to calculated $\mathrm{OH}$ reactivity only rather than modelled reactivity; the latter would include an estimate of the contribution that modelgenerated intermediates make to the total loss rate. The fact that closure has previously been obtained using calculated reactivity from primary emissions alone suggests that oxidised intermediates do not always contribute significantly to the total $\mathrm{OH}$ reactivity in certain cities. This is not the case at all urban sites, for example Chatani et al. (2009) reported a missing reactivity of $\sim 30 \%$ in Tokyo during the summer determined by comparing the measured $\mathrm{OH}$ reactivity with that calculated from measured sinks, and concluded that oxidised intermediates likely contributed to the missing fraction. Sim- 
ilarly, Dolgorouky et al. (2012) reported a missing reactivity of $75 \%$ when continental air was sampled in Paris during the wintertime MEGAPOLI project and only measured sinks were used to calculate $k_{\mathrm{OH}}$. The closure of the $\mathrm{OH}$ reactivity budget in certain cities such as Houston (Mao et al., 2010) and New York (Ren et al., 2003) may reflect the dominance of $\mathrm{NO}_{x}$ acting as main $\mathrm{OH}$ sink, a species from which no model-generated intermediates will derive (in New York the reaction of $\mathrm{OH}$ with $\mathrm{NO}$ and $\mathrm{NO}_{2}$ accounted for $50 \%$ of the total $\mathrm{OH}$ reactivity, Ren et al., 2003). The VOC classes which dominate in different cities may also be substantially different (and, hence, their propensity to generate intermediates may differ). For example, aromatics account for up to $15 \%$ of the total reactivity in Houston (Mao et al., 2010) where local petrochemical industries can influence the local air mass composition. In contrast, aromatics accounted for just $5 \%$ of the total reactivity in Tokyo (Yoshino et al., 2012) during the summer of 2007. During the PRIDE-PRD campaign in southern China, $\mathrm{OH}$ reactivity was modelled using the Regional Atmospheric Chemistry Model (RACM) and, alongside calculated $\mathrm{OH}$ reactivity from measured sinks, was compared to measured $\mathrm{OH}$ reactivity. Lou et al. (2010) found that the calculated $\mathrm{OH}$ reactivity was a factor of 2 less than the measured value, whereas the RACM-modelled $\mathrm{OH}$ reactivity reproduced the observations well, suggesting that unmeasured secondary species (mainly thought to be OVOCs) do make a significant contribution to the total observed $\mathrm{OH}$ reactivity. During the daytime the PRIDE-PRD site was heavily influenced by biogenic emissions, in contrast to some of the urban sites discussed above, which may in part explain the differences of the missing $\mathrm{OH}$ reactivity reported.

Care is needed when comparing the missing $\mathrm{OH}$ reactivity reported in the literature, as the chemical detail and range of measured VOCs and inorganic (e.g. $\mathrm{NO}_{x}, \mathrm{CO}, \mathrm{O}_{3}$ ) species which have been used to calculate $\mathrm{OH}$ reactivity varies significantly between projects. Oxygenated VOCs or biogenic VOCs (in addition to isoprene) are often measured, although this is not always the case as in the urban studies reported by Lou et al., (2010); Kovacs et al. (2003); Ren et al. (2003); Mao et al. (2010); Dolgorouky et al. (2012).

This paper presents an extensive data set of $\mathrm{OH}$ reactivity measured in London during the summer of 2012 as part of the Clean air for London (ClearfLo) project (Bohnenstengel et al., 2015). Alongside $\mathrm{OH}$ reactivity, an extremely comprehensive speciated VOC data set was measured and used to constrain a zero-dimensional box model based on the Master Chemical Mechanism v3.2 in order to model OH reactivity. By comparing modelled and measured reactivity, the level of missing $\mathrm{OH}$ reactivity is quantified. By also constraining the model with a subset of the VOCs comprising the more commonly reported $\mathrm{C}_{2}-\mathrm{C}_{8}$ VOCs (measured using a dual-channel gas chromatography system), we assess which classes of $\mathrm{VOC}$ are controlling the $\mathrm{OH}$ reactivity in London. Using the model we also investigate the impact of various classes of VOC on the concentration of peroxy radi- cal species and consequently on the magnitude of in situ $\mathrm{O}_{3}$ production.

\section{Experimental}

\subsection{Site description}

The ClearfLo campaign ran from 22 July to 18 August and overlapped with the London 2012 summer Olympics. An extensive suite of instrumentation was deployed and operated from the grounds of Sion Manning School in North Kensington $\left(51^{\circ} 31^{\prime} 61^{\prime \prime} \mathrm{N}, 0^{\circ} 12^{\prime} 48^{\prime \prime} \mathrm{W}\right)$, which is located adjacent to a long-term air quality monitoring site in North Kensington (Bigi and Harrison, 2010). Further details on the campaign and location may be found in the ClearfLo overview paper (Bohnenstengel et al., 2015). The inlets for the $\mathrm{OH}$ reactivity instrument and those for measuring $\mathrm{OH}$ sinks were within $5 \mathrm{~m}$ of one another horizontally, and $1 \mathrm{~m}$ vertically.

\subsection{OH reactivity measurements}

$\mathrm{OH}$ reactivity measurements were made using the laser flash photolysis pump-probe technique (Sadanaga et al., 2004), and the instrument is described in detail in Stone et al. (2016). Ambient air was drawn into a reaction cell $(85 \mathrm{~cm}$ in length; $5 \mathrm{~cm}$ internal diameter), at a flow rate of $12 \mathrm{slm}$, by an extraction fan situated at the far end of the reaction cell to the inlet. A flow of $0.5 \mathrm{slm}$ of humidified ultra-high purity air (BTCA 178, BOC Special Gases) was passed across a lowpressure $\mathrm{Hg}$ lamp, generating $\sim 50 \mathrm{ppb}_{3}$, and mixed with the ambient air flow. Laser photolysis of $\mathrm{O}_{3}$ at $266 \mathrm{~nm}$ gave uniform production of $\mathrm{OH}$ along the length of the reaction cell following the reaction of $\mathrm{O}\left({ }^{1} \mathrm{D}\right)$ with water vapour.

Changes in $\mathrm{OH}$ radical concentrations owing to pseudofirst-order loss with species present in ambient air were monitored by sampling air from the reaction cell through a $0.8 \mathrm{~mm}$ pinhole into a FAGE (fluorescence assay by gas expansion) detection cell maintained at a pressure of $\sim 1.5$ Torr by a Roots blower backed by a rotary pump. The $308 \mathrm{~nm}$ probe laser, operating at a pulse repetition frequency of $5 \mathrm{kHz}$, was passed across the gas flow in the FAGE cell to excite $\mathrm{OH}$ radicals, with the subsequent laser-induced fluorescence signal at $\sim 308 \mathrm{~nm}$ detected by a gated channel photomultiplier tube. The $\mathrm{OH}$ decay profile owing to reactions with species in ambient air is thus detected in real time.

Decay profiles were averaged for 5 min periods, and fitted to a first-order rate equation to find the rate coefficient describing the observed loss of $\mathrm{OH}\left(k_{\text {loss }}\right)$. The $\mathrm{OH}$ reactivity, $k_{\mathrm{OH}}$, was determined by subtracting the rate coefficient describing physical losses of $\mathrm{OH}\left(k_{\text {phys }}\right)$ from the observed loss of $\mathrm{OH}$ in ambient air, with a small correction to account for the dilution of ambient air with the small flow of $\mathrm{O}_{3}$-containing humidified ultra-high purity air. The rate coefficient, $k_{\text {phys }}$, was determined by monitoring the loss of $\mathrm{OH}$ when sampling ultra-high purity air (BTCA 178, BOC 
Special Gases, passed through scrubbers to remove trace amounts of $\mathrm{NO}_{x}, \mathrm{H}_{2}, \mathrm{CO}$ and $\mathrm{CO}_{2}$ ) containing the same small flow of $\mathrm{O}_{3}$-containing humidified ultra-high purity air as for the measurements sampling ambient air, and was found to be $1.1 \pm 1.0 \mathrm{~s}^{-1}$.

The accuracy of the $\mathrm{OH}$ reactivity measurements was verified in the laboratory by measuring the bimolecular rate coefficients for reactions of $\mathrm{OH}$ with $\mathrm{CO}$ and $\mathrm{CH}_{4}$ under pseudofirst-order conditions at $298 \mathrm{~K}$. For reaction of $\mathrm{OH}$ with $\mathrm{CO}$, a bimolecular rate coefficient of $(2.4 \pm 0.2) \times 10^{-13} \mathrm{~cm}^{3} \mathrm{~s}^{-1}$ was determined, in agreement with the literature value of $2.3 \times 10^{-13} \mathrm{~cm}^{3} \mathrm{~s}^{-1}$ (Atkinson et al., 2006), and for $\mathrm{OH}+$ $\mathrm{CH}_{4}$, a rate coefficient of $(6.4 \pm 0.6) \times 10^{-15} \mathrm{~cm}^{3} \mathrm{~s}^{-1}$ was determined, in agreement with the literature value of $6.4 \times$ $10^{-15} \mathrm{~cm}^{3} \mathrm{~s}^{-1}$ (Atkinson et al., 2006). The $1 \sigma$ uncertainty of the measurements was, on average, $\pm 3.2 \mathrm{~s}^{-1}$, reflecting the combined uncertainties from the fits of the observed $\mathrm{OH}$ decays, determinations of $k_{\text {phys }}$ and uncertainties in the dilution factor.

\subsection{VOC measurements}

Two gas chromatography (GC) instruments were deployed as part of the summer ClearfLo campaign for in situ VOC measurements: a dual-channel gas chromatography flame ionisation detector, (DC)-GC-FID, measuring the very volatile VOCs $\left(\mathrm{C}_{2}-\mathrm{C}_{8}\right.$ hydrocarbons and a small selection of OVOCs) with effective saturation concentrations ranging from $3 \times 10^{7}$ to $1.4 \times 10^{12} \mu \mathrm{g} \mathrm{m}^{-3}$, and a comprehensive twodimensional GC $(\mathrm{GC} \times \mathrm{GC}$-FID) which measured the less volatile fraction, $\left(\mathrm{C}_{6}-\mathrm{C}_{13}\right.$ and a large group of OVOCS) with effective saturation concentrations ranging from $1.8 \times 10^{6}$ to $2.4 \times 10^{9} \mu \mathrm{g} \mathrm{m}^{-3}$. The combined sampling and separation time of the systems allowed a time resolution of approximately $1 \mathrm{~h}$. The details of these two instruments and the time series of the VOC measurements during ClearfLo are presented in Dunmore et al. (2015). A total of 64 VOCs were individually identified and quantified and used to constrain a zero-dimensional box model; these are listed in Table 1 . Many hundreds more were included in a carbon number and functionality grouping in an attempt to quantify as much of the reactive carbon loading as possible (Dunmore et al., 2015).

\subsection{Model description}

A zero-dimensional box model, utilising a subset of the chemistry described within the Master Chemical Mechanism MCMv3.2 (Jenkin et al., 2012), has been used to predict OH reactivity for comparison with the measured reactivity. In its entirety, the MCM treats the degradation of 135 VOCs following oxidation by $\mathrm{OH}, \mathrm{O}_{3}$ and $\mathrm{NO}_{3}$, and for alkanes only, oxidation by $\mathrm{Cl}$ atoms, and contains $\sim 6700$ species and $\sim 17000$ reactions. Complete details of the kinetic and pho- tochemical data used in the mechanism are available on the MCM website (MCM, http://mcm.leeds.ac.uk/MCM/).

The model was constrained to measurements of $\mathrm{NO}, \mathrm{NO}_{2}$, $\mathrm{O}_{3}, \mathrm{HONO}, \mathrm{CO}, \mathrm{CH}_{4}$, PAN, formaldehyde (HCHO), VOCs (details given in Table 1), water vapour, temperature, pressure, photolysis frequencies (using actinic fluxes measured by a spectral radiometer) and aerosol surface area. A constant $\mathrm{H}_{2}$ concentration of $500 \mathrm{ppbV}$ was assumed.

The model inputs were updated every $15 \mathrm{~min}$. For species measured more frequently, data were averaged to $15 \mathrm{~min}$ intervals, whilst those measured at a lower time resolution, for example the VOCs (Table 1), were interpolated. By this method, a model time series was produced which could be directly compared with the $\mathrm{OH}$ reactivity and radical observations and from which diurnal averages were also generated.

The loss of all non-constrained, model-generated species by deposition was represented by a deposition velocity equivalent to $1 \mathrm{~cm} \mathrm{~s}^{-1}$. The mixing height was constrained to measurements made by a lidar instrument (Barlow et al., 2011) and was observed to rapidly increase after sunrise up to a height of $\sim 1800 \mathrm{~m}$ from a minimum of $\sim 330 \mathrm{~m}$ at $\sim$ 04:00.

The model was run for the entirety of the campaign in overlapping 7-day segments. To allow all the unmeasured, model-generated intermediate species time to reach steadystate concentrations the model was initialised with inputs from the first measurement day (22 July 2012) for 5 days before comparison to measurements were made. Comparison of these 5 spin-up days demonstrated that the concentration of model-generated species rapidly converged and there was less than a $1 \%$ difference in (for example) modelled $\mathrm{OH}$ concentration by the second spin-up day. As a result of this, the model segments were run so as to overlap for 2 days only to reduce the computing time.

\section{Results}

Near-continuous $\mathrm{OH}$ reactivity measurements were made in London from 22 July to 17 August 2012 and a comprehensive suite of individually measured inorganic and organic $\mathrm{OH}$ sink species were made alongside, as detailed in Table 1. The $\mathrm{OH}$ reactivity time series is presented in Fig. $1 \mathrm{~b}$ and c. Typically, south-westerly winds ranging from less than $1 \mathrm{~m} \mathrm{~s}^{-1}$ during the night to between 4 and $6 \mathrm{~m} \mathrm{~s}^{-1}$ in the afternoon were encountered. However, close to the start of the campaign (24-27 July) and also later in the campaign (8-10 August), the wind direction switched to an easterly flow, bringing air that had passed over central London to the site, and wind speeds dropped. Fine weather prevailed during these easterly flows, with enhancements in air temperature and solar radiation observed (Bohnenstengel et al., 2015). During these periods, radical concentrations were elevated, as were the concentration of a number of other species such as $\mathrm{NO}_{x}$, $\mathrm{HCHO}$, ozone and many of the individually detected VOCs. 
Table 1. Species used as input to the model, the class each species is grouped into, the average contribution ( $\mathrm{s}^{-1}$ and $\%$ ) of each class to $\mathrm{OH}$ reactivity and the detection method for each species. The $\mathrm{OH}$ reactivity when the concentration of the unassigned GC $\times$ GC-FID peaks is also considered is given in parentheses.

\begin{tabular}{|c|c|c|c|c|}
\hline Species (MCM name) & Class & $\begin{array}{l}\text { Contribution to } \\
\text { OH reactivity } \\
\left(\mathrm{s}^{-1}\right)\end{array}$ & $\begin{array}{l}\text { Contribution to } \\
\text { OH reactivity } \\
(\%)\end{array}$ & Instrument \\
\hline $\mathrm{O} 3$ & $\mathrm{O}_{3}$ & $0.05^{*}$ & 0.3 & Thermo 49 Series \\
\hline NO & NO & 0.76 & 4.2 & $\begin{array}{l}\text { Air Quality Design Inc. Chemi- } \\
\text { luminescence with LED } \mathrm{NO}_{2} \\
\text { converter }\end{array}$ \\
\hline $\mathrm{NO} 2$ & $\mathrm{NO}_{2}$ & 3.82 & 21.1 & \\
\hline $\mathrm{CO}$ & $\mathrm{CO}$ & 1.31 & 7.2 & Ametek monitor \\
\hline $\mathrm{H} 2$ & $\mathrm{H}_{2}$ & $0.08^{*}$ & 0.4 & - \\
\hline $\begin{array}{l}\text { HONO } \\
\text { HNO3 } \\
\text { PAN }\end{array}$ & $\mathrm{NO}_{z}$ & $0.04 *$ & 0.2 & $\begin{array}{l}\text { LOPAP } \\
\text { CIMS } \\
\text { GC-ECD }\end{array}$ \\
\hline $\begin{array}{l}\mathrm{CH} 3 \mathrm{OH} \\
\mathrm{C} 2 \mathrm{H} 5 \mathrm{OH} \\
\text { NPROPOL } \\
\text { NBUTOL }\end{array}$ & Alcohol & 0.54 & 3.0 & $\begin{array}{l}\text { (DC)-GC-FID } \\
\text { (DC)-GC-FID } \\
\text { (DC)-GC-FID } \\
\text { (DC)-GC-FID }\end{array}$ \\
\hline $\begin{array}{l}\text { CH4 } \\
\text { C2H6 } \\
\text { C3H8 } \\
\text { IC4H10 } \\
\text { NC4H10 } \\
\text { IC5H12 } \\
\text { NC5H12 } \\
\text { NC6H14 } \\
\text { NC7H16 } \\
\text { NC8H18 } \\
\text { M2PE } \\
\text { NC9H20 } \\
\text { NC10H22 } \\
\text { NC11H24 } \\
\text { NC12H26 } \\
\text { CH2CL2 }\end{array}$ & Alkane & $0.81(1.22)$ & $4.5(6.7)$ & $\begin{array}{l}\text { (DC)-GC-FID } \\
\text { (DC)-GC-FID } \\
\text { (DC)-GC-FID } \\
\text { (DC)-GC-FID } \\
\text { (DC)-GC-FID } \\
\text { (DC)-GC-FID } \\
\text { (DC)-GC-FID } \\
\text { (DC)-GC-FID \& GC } \times \text { GC-FID } \\
\text { (DC)-GC-FID \& GC } \times \text { GC-FID } \\
\text { (DC)-GC-FID \& GC } \times \text { GC-FID } \\
\text { (DC)-GC-FID } \\
\text { GC } \times \text { GC-FID } \\
\text { GC } \times \text { GC-FID } \\
\text { GC } \times \text { GC-FID } \\
\text { GC } \times \text { GC-FID } \\
\text { GC } \times \text { GC-FID }\end{array}$ \\
\hline $\begin{array}{l}\mathrm{C} 2 \mathrm{H} 2 \\
\mathrm{C} 2 \mathrm{H} 4 \\
\text { C3H6 } \\
\text { TBUT2ENE } \\
\text { BUT1ENE } \\
\text { MEPROPENE } \\
\text { CBUT2ENE } \\
\text { PENT2ENE } \\
\text { PENT1ENE } \\
\text { TRICLETH }\end{array}$ & $\begin{array}{l}\text { Alkene and } \\
\text { Alkyne }\end{array}$ & 0.47 & 2.6 & $\begin{array}{l}\text { (DC)-GC-FID } \\
\text { (DC)-GC-FID } \\
\text { (DC)-GC-FID } \\
\text { (DC)-GC-FID } \\
\text { (DC)-GC-FID } \\
\text { (DC)-GC-FID } \\
\text { (DC)-GC-FID } \\
\text { (DC)-GC-FID } \\
\text { (DC)-GC-FID } \\
\text { GC } \times \text { GC-FID }\end{array}$ \\
\hline
\end{tabular}


Table 1. Continued.

\begin{tabular}{|c|c|c|c|c|}
\hline Species (MCM name) & Class & $\begin{array}{l}\text { Contribution to } \\
\text { OH reactivity } \\
\left(s^{-1}\right)\end{array}$ & $\begin{array}{l}\text { Contribution to } \\
\text { OH reactivity } \\
(\%)\end{array}$ & Instrument \\
\hline $\begin{array}{l}\text { BENZENE } \\
\text { TOLUENE } \\
\text { EBENZ } \\
\text { MXYL } \\
\text { PXYL } \\
\text { OXYL } \\
\text { TM123B } \\
\text { TM135B } \\
\text { TM124B } \\
\text { STYRENE } \\
\text { IPBENZ } \\
\text { PBENZ } \\
\text { METHTOL } \\
\text { PETHTOL } \\
\text { OETHTOL } \\
\text { BENZAL }\end{array}$ & Aromatic & $0.235(0.24)$ & $1.3(1.3)$ & $\begin{array}{l}\text { (DC)-GC-FID } \\
\text { (DC)-GC-FID } \\
\text { (DC)-GC-FID } \\
\text { (DC)-GC-FID } \\
\text { (DC)-GC-FID } \\
\text { (DC)-GC-FID } \\
\text { (DC)-GC-FID \& GC } \times \text { GC-FID } \\
\text { (DC)-GC-FID \& GC } \times \text { GC-FID } \\
\text { (DC)-GC-FID \& GC } \times \text { GC-FID } \\
\text { GC } \times \text { GC-FID } \\
\text { GC } \times \text { GC-FID } \\
\text { GC } \times \text { GC-FID } \\
\text { GC } \times \text { GC-FID } \\
\text { GC } \times \text { GC-FID } \\
\text { GC } \times \text { GC-FID } \\
\text { GC } \times \text { GC-FID }\end{array}$ \\
\hline $\begin{array}{l}\text { APINENE } \\
\text { LIMONENE }\end{array}$ & Biogenic & $0.25(0.33)$ & $1.4(1.8)$ & $\begin{array}{l}\mathrm{GC} \times \mathrm{GC}-\mathrm{FID} \\
\mathrm{GC} \times \mathrm{GC}-\mathrm{FID}\end{array}$ \\
\hline $\begin{array}{l}\mathrm{HCHO} \\
\mathrm{CH} 3 \mathrm{CHO} \\
\mathrm{CH} 3 \mathrm{COCH} 3 \\
\text { MACR } \\
\text { MVK } \\
\text { IPRCHO } \\
\text { ETHACET } \\
\text { MEK } \\
\text { C3H7CHO } \\
\text { MPRK } \\
\text { C4H9CHO } \\
\text { MIBK } \\
\text { HEX2ONE } \\
\text { CYHEXONE }\end{array}$ & Carbonyl & 3.45 & 19.1 & $\begin{array}{l}\text { Aerolaser } 4021 \text { analyser } \\
(\text { DC)-GC-FID } \\
(D C) \text {-GC-FID } \\
(\text { DC)-GC-FID \& GC } \times \text { GC-FID } \\
(D C) \text {-GC-FID \& GC } \times \text { GC-FID } \\
\text { GC } \times \text { GC-FID } \\
\text { GC } \times \text { GC-FID } \\
\text { GC } \times \text { GC-FID } \\
\text { GC } \times \text { GC-FID } \\
\text { GC } \times \text { GC-FID } \\
\text { GC } \times \text { GC-FID } \\
\text { GC } \times \text { GC-FID } \\
\text { GC } \times \text { GC-FID } \\
\text { GC } \times \text { GC-FID }\end{array}$ \\
\hline $\begin{array}{l}\mathrm{C} 4 \mathrm{H} 6 \\
\mathrm{C} 5 \mathrm{H} 8\end{array}$ & Dialkene & 0.32 & 1.8 & $\begin{array}{l}\text { (DC)-GC-FID } \\
\text { (DC)-GC-FID }\end{array}$ \\
\hline Model intermediates & $\begin{array}{l}\text { Model } \\
\text { intermediates }\end{array}$ & $3.2(4.3)$ & $17.7(23.8)$ & - \\
\hline
\end{tabular}

* The contributions of classes which account for less than $0.1 \mathrm{~s}^{-1} \mathrm{OH}$ reactivity are not plotted in Figs. 2, 3, 5 and 6 for clarity.

$\mathrm{OH}$ reactivity was also observed to increase during the easterly flows, with a peak reactivity of $116 \mathrm{~s}^{-1}$ recorded in the morning (07:00 GMT, which is local time (BST) $-1 \mathrm{~h})$ of the 24 July.

On all days a distinct diurnal trend was apparent in $\mathrm{OH}$ reactivity, which peaked between 6:00 and 07:00 (GMT) and then dropped to a minimum during the afternoon as shown in Fig. 2. A broader, less distinct secondary peak in reactivity was observed after 18:00, continuing throughout the night. This trend is typical of the $\mathrm{OH}$ reactivity profile observed at urban sites (e.g. Dolgorouky et al., 2012; Sadanaga et al.,
2005; Chatani et al., 2009; Lou et al., 2010), and closely follows the observed $\mathrm{NO}_{x}$ profile. The mean reactivity for the campaign was $18.1 \mathrm{~s}^{-1}$ and on average the reaction of $\mathrm{OH}$ with $\mathrm{NO}$ and $\mathrm{NO}_{2}$ accounted for $4.5 \mathrm{~s}^{-1}(25 \%)$ of the reactivity observed. The reaction with $\mathrm{CO}$ accounted for a further $1.3 \mathrm{~s}^{-1}(7 \%)$ and so it is evident, by considering the reactivity that remains unaccounted for, that the combined contribution made by organic compounds must be significant. The model was initially run constrained to the standard set of VOCs measured by the (DC)-GC-FID. The rate of loss of $\mathrm{OH}$ by reaction with each individual VOC com- 


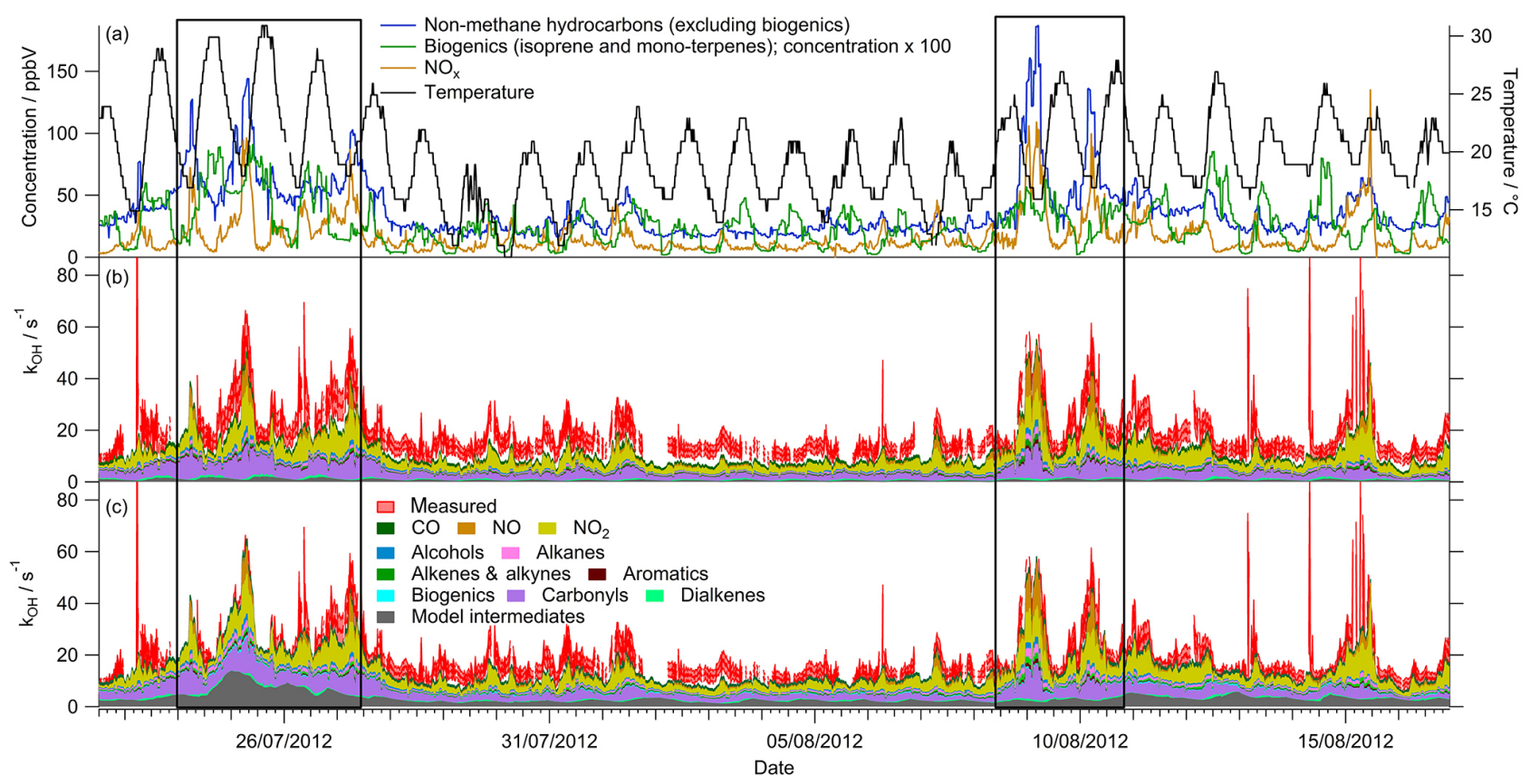

Figure 1. (a) Time series of non-methane hydrocarbons (excluding biogenics), biogenics (isoprene and monoterpenes), $\mathrm{NO}_{x}$ and temperature, (b) measured $\mathrm{OH}$ reactivity time series and breakdown of modelled $\mathrm{OH}$ reactivity when only the standard set of VOCs are used as model constraints and (c) measured $\mathrm{OH}$ reactivity time series and breakdown of modelled $\mathrm{OH}$ reactivity when VOCs measured by the dual-channel GC-FID and GC $\times$ GC-FID instruments are used as model constraints (see Table 1 for details). Periods of more polluted easterly flows are highlighted. The averaging period is $15 \mathrm{~min}$. The $1 \sigma$ uncertainty of the $\mathrm{OH}$ reactivity measurements (red shading) was, on average, $\pm 3.2 \mathrm{~s}^{-1}$.

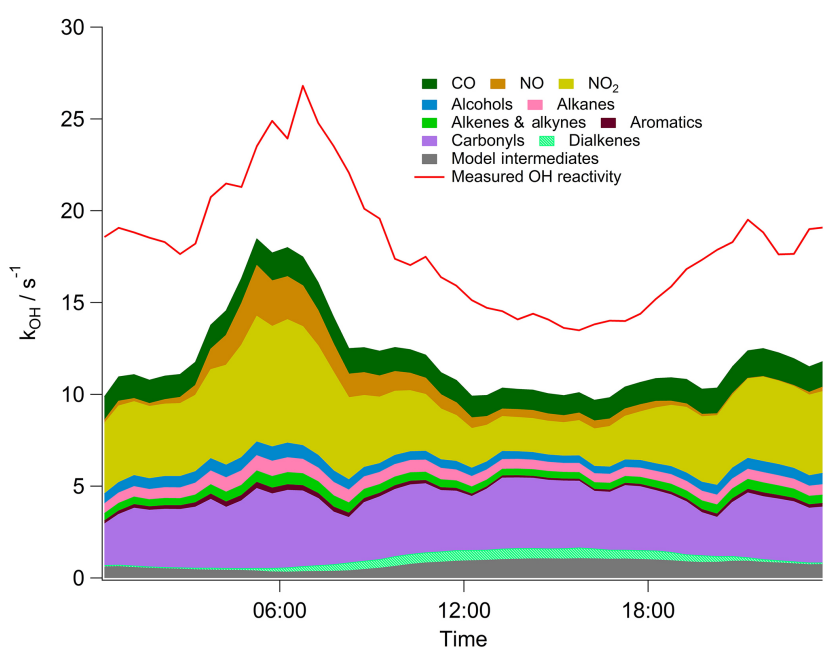

Figure 2. Average diurnal profile of measured reactivity for the entire ClearfLo campaign and a breakdown of modelled reactivity into inorganic and organic classes when the model is constrained to the standard VOC suite measured by the (DC)-GC-FID instrument. See Table 1 for details of the individual VOCs that were measured.

pound is extremely small, so by grouping individual VOCs detected by the (DC)-GC-FID by class (alcohol, alkanes, alkenes and alkynes, aromatics, carbonyls and dialkenes) the influence of different $\mathrm{VOC}$ types on the removal of $\mathrm{OH}$ and hence their influence on the oxidising capacity can be evaluated. Using this approach, for the carbonyl class of VOCs the reactivity towards $\mathrm{OH}$ is dominated by $\mathrm{HCHO}(40 \%)$ and acetaldehyde (54\%), and when considered as a whole, makes a similar contribution as $\mathrm{NO}_{2}$ to the total $\mathrm{OH}$ reactivity. The other organic classes contribute less to total reactivity (between 0.2 and $0.6 \mathrm{~s}^{-1}$ on average), with reactivity from most of the classes exhibiting a weak diurnal profile similar to that of $\mathrm{NO}_{x}$. In contrast, the contribution to $\mathrm{OH}$ reactivity made by the dialkene class, which itself is dominated by isoprene, peaks at noon suggesting a dominance of a temperature-/sunlight-driven biogenic signature as opposed to a traffic signature for this class.

Combined, the contribution of $\mathrm{NO}_{x}, \mathrm{CO}$ and all measured organic classes cannot reconcile the $\mathrm{OH}$ reactivity observed, with an average missing reactivity of $6.7 \mathrm{~s}^{-1}$ which equates to $37 \%$ of the total measured value. Even when model-generated intermediates are considered, which are made up largely by oxygenated compounds such as methylglyoxal, glyoxal and glycoaldehyde which derive from aromatic species, isoprene and methyl vinyl ketone, on average, $6.0 \mathrm{~s}^{-1}$ of $\mathrm{OH}$ reactivity ( $33 \%$ of the total measured) remains unaccounted for, as shown in Fig. 2.

An extended range of VOCs ( 24 additional compounds), consisting of $n$-alkanes, substituted aromatic and carbonyl compounds and the monoterpenes of $\alpha$-pinene and limonene, were detected using a GC $\times$ GC-FID instrument. The missing 


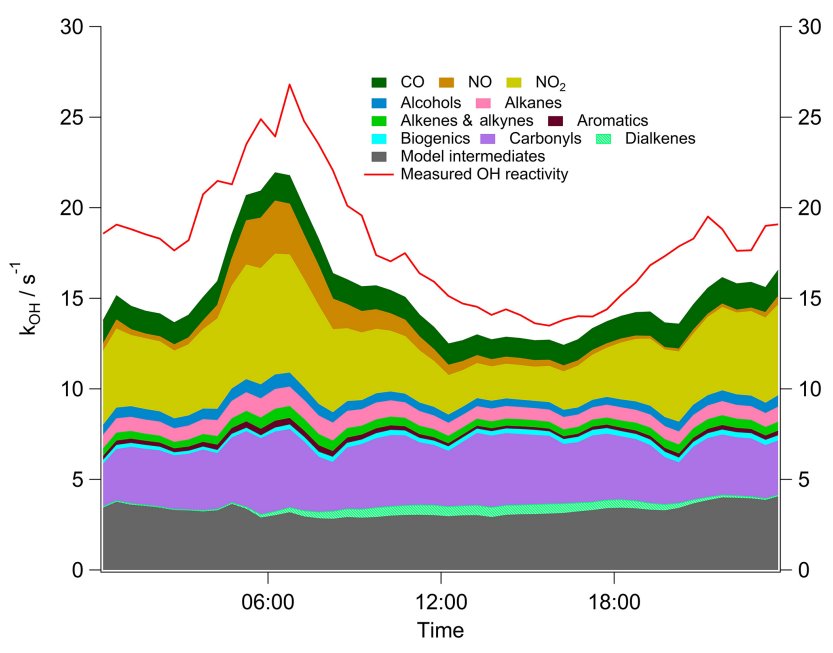

Figure 3. Average diurnal profile of measured reactivity and a breakdown of modelled reactivity into inorganic and organic classes when the model is constrained to the standard VOC suite measured by the (DC)-GC-FID and additional VOCs (including $\alpha$-pinene and limonene; see Table 1 for details) measured by GC $\times$ GC-FID.

reactivity determined in the modelling exercise above (which included only VOCs from the (DC)-GC-FID) may derive from these additional VOCs which, historically, are not typically detected by traditional GC methodologies. As shown in Fig. 3, the reaction of $\mathrm{OH}$ with the biogenic species $\alpha$ pinene and limonene alone (not including any model-derived intermediates) increases the total calculated $\mathrm{OH}$ reactivity by $0.25 \mathrm{~s}^{-1}$, and similar increases are calculated by inclusion of the additional $n$-alkanes detected (Table 1). Overall, however, calculated $\mathrm{OH}$ reactivity increases by just $0.7 \mathrm{~s}^{-1}$ on average when these additional contributions are considered without including model-derived intermediates. Interestingly, the contribution that the model-derived intermediates make to $\mathrm{OH}$ reactivity when the model is run constrained to the extended VOC suite is much more significant than previously presented in Fig. 2. When combined, the modelgenerated intermediates contribute $3.2 \mathrm{~s}^{-1}$ on average to the $\mathrm{OH}$ reactivity in the model run constrained to the extended VOC measurements, compared to just $0.7 \mathrm{~s}^{-1}$ in the model run constrained just with the standard VOC measurements.

In total there are close to 2600 reactions included in the extended VOC model run which destroy $\mathrm{OH}$, and the reaction of $\mathrm{OH}$ with the different model-generated intermediate species accounts for more than $90 \%$ of these reactions. Pinonaldehyde (an oxidation product of $\alpha$-pinene formed both during ozonolysis and $\mathrm{OH}$-initiated oxidation reactions) is the most destructive model intermediate species with respect to $\mathrm{OH}$ and this single species is found to contribute approximately $7.5 \%$ to the total $\mathrm{OH}$ reactivity of the modelled intermediates at noon. Considering the top ten most destructive model intermediates which account for roughly $30 \%$ of the total model intermediate reactivity, nine out of the ten derive from biogenic species. Species which derive from $\alpha$-pinene account for two-thirds of the reactivity of the top ten intermediate species, whilst those which derive from limonene account for approximately one third. 3Hydroxypropanal, which derives from the alkane class and is the tenth most destructive model intermediate, contributes $\sim 1.5 \%$ to the total reactive of the intermediates on average. To determine the absolute impact of the biogenic species on $\mathrm{OH}$ reactivity, a model was run constrained to all (DC)GC-FID and GC $\times$ GC-FID VOC measurements apart from $\alpha$-pinene and limonene. The model-generated intermediates from this run contributed $1.04 \mathrm{~s}^{-1}$ to total $\mathrm{OH}$ reactivity on average, demonstrating that although the contribution to total $\mathrm{OH}$ reactivity from the measured biogenic class (considering only reaction with the parent VOCs) was small $\left(0.25 \mathrm{~s}^{-1}\right)$, the oxidation products from just $\alpha$-pinene and limonene alone account for $2.2 \mathrm{~s}^{-1}$ of the $\mathrm{OH}$ reactivity. The total concentration of $\mathrm{C}_{9}-\mathrm{C}_{12}$ alkanes is $\sim 5$ times greater than the combined concentration of the biogenics on average. Despite this, the model intermediates generated during the oxidation of these larger alkanes $\left(\mathrm{C}_{9}-\mathrm{C}_{12}\right)$ which derive from diesel emissions (Dunmore et al., 2015), and the intermediates generated from the additional aromatic and carbonyl species detected by GC $\times$ GC-FID, contribute only $0.34 \mathrm{~s}^{-1}$ to total reactivity on average. The rate of reaction of $\mathrm{OH}$ with $\alpha$-pinene $\left(5 \times 10^{-11} \mathrm{~cm}^{3}\right.$ molecule ${ }^{-1} \mathrm{~s}^{-1}$ at $298 \mathrm{~K}$ ) is approximately 4.5 times faster (and the reaction with limonene $\left(1.6 \times 10^{-10} \mathrm{~cm}^{3}\right.$ molecule ${ }^{-1} \mathrm{~s}^{-1}$ at $\left.298 \mathrm{~K}\right)$ is an order of magnitude faster) than the analogous reactions with the $\mathrm{C}_{9}-\mathrm{C}_{12}$ alkanes $\left(\sim 1.2 \times 10^{-11} \mathrm{~cm}^{3}\right.$ molecule ${ }^{-1} \mathrm{~s}^{-1}$ at $298 \mathrm{~K}$ ). Furthermore, the initial reaction of these biogenic species with ozone can also contribute to the formation of the biogenic-derived model intermediates species. The biogenic intermediates themselves remain highly reactive towards $\mathrm{OH}$, with the rate coefficient for the reaction of $\mathrm{OH}$ with pinonaldehyde being similar to the rate coefficient for the reaction of $\mathrm{OH}$ with $\alpha$-pinene itself $\left(4 \times 10^{-11}\right.$ and $5 \times 10^{-11} \mathrm{~cm}^{3}$ molecule $\mathrm{s}^{-1} \mathrm{~s}^{-1}$ respectively at $298 \mathrm{~K}$ ). These factors combined lead to the biogenic species strongly influencing $\mathrm{OH}$ reactivity.

The contribution that modelled intermediates derived from the larger VOCs (measured by the GC $\times$ GC-FID) make to the total $\mathrm{OH}$ reactivity is significant, and is able to largely close the gap between modelled and observed $\mathrm{OH}$ reactivity, with $\sim 15 \%$ missing reactivity remaining. Good agreement both in terms of the magnitude and variability from the day-today (Fig. 1) and campaign average diurnal profile (Fig. 3) is achieved by the model when constrained to the extended VOC measurements. This result highlights the impact of biogenic VOCs in London when the oxidised secondary products are considered. The role of biogenic VOCs (excluding isoprene) in increasing the $\mathrm{OH}$ reactivity has not previously been demonstrated at urban sites. Often biogenic VOCs other than isoprene are not measured at urban sites when $\mathrm{OH}$ reactivity has been reported (e.g. Kovacs et al., 2003; Ren et al., 


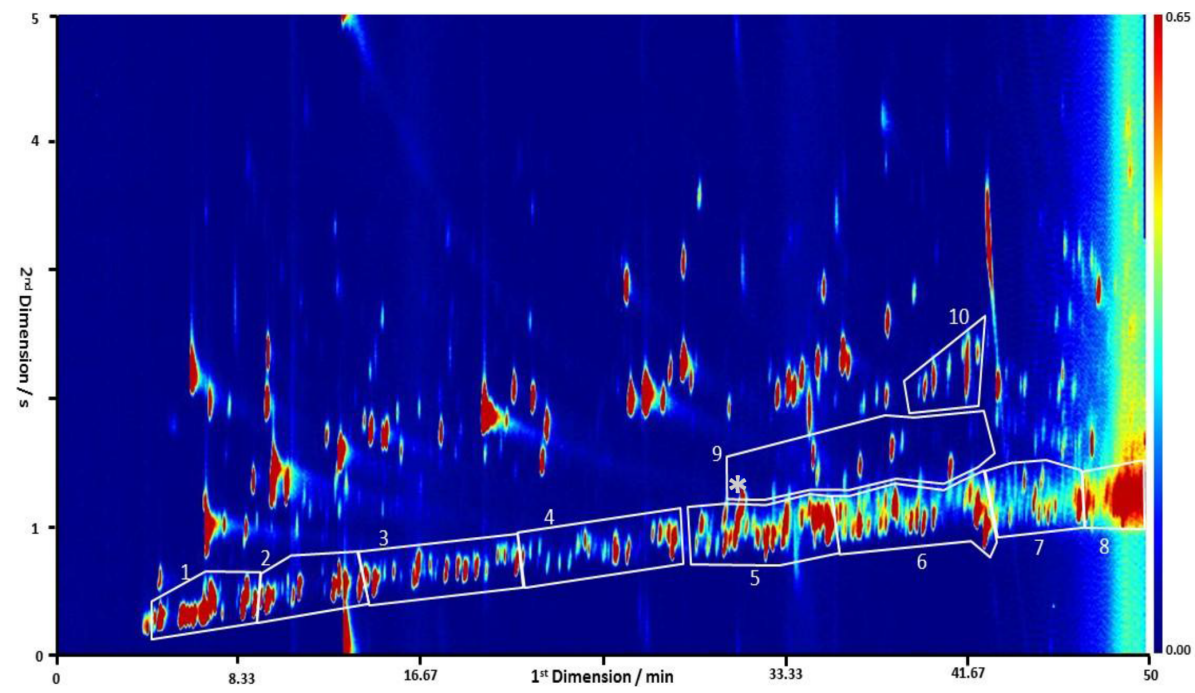

Figure 4. A typical GC $\times$ GC chromatogram from the summer ClearfLo campaign. The retention times from column 1 (separation based on volatility) and column 2 (separation based on polarity) are the $x$ and $y$ axis respectively, and compound intensity is the coloured contour. Labelled groups are identified as follows: (1-8) aliphatic groups from $\mathrm{C}_{6}$ to $\mathrm{C}_{13}$, (9) $\mathrm{C}_{10}$ monoterpenes with $*$ corresponding to $\alpha$-pinene which is the start of that group and (10) $\mathrm{C}_{4}$ substituted monoaromatics.

2003; Mao et al., 2010; Lou et al., 2010; Dolgorouky et al., 2012) and even if they are measured, the contribution they make to total $\mathrm{OH}$ reactivity is deemed small if only the reaction of the parent-measured biogenic species with $\mathrm{OH}$ is considered (e.g. Chatani et al., 2009). The ultimate fate of these oxidised intermediates derived from biogenic VOCs is highly uncertain, but if they remain in the gas phase, as opposed to partitioning onto particles, their potential to increase the rate of radical propagation and in situ ozone production is significant.

Even when the contribution made to reactivity from the additional VOCs measured by the GC $\times$ GC-FID is taken into account, a small missing reactivity ( $\sim 15 \%$ on average) remains. This missing reactivity could suggest that the physical loss of model-generated intermediates may actually be slower than imposed in the model (see Sect. 3.2) or this under-prediction in $\mathrm{OH}$ reactivity could also reflect further missing primary $\mathrm{OH}$ sinks, for example, higher molecular weight carbon $\left(\geqslant \mathrm{C}_{13}\right)$ that is not detected by either the (DC)GC-FID or GC $\times$ GC-FID methods employed. It is known that $\geqslant \mathrm{C}_{13}$ makes up a large fraction of diesel emissions, and diesel-related hydrocarbons have been shown to dominate the gas-phase carbon (in terms of mass) in London (Dunmore et al., 2015).

The complexity of London's air can be observed in the GC $\times$ GC-FID chromatogram shown in Fig. 4. In addition to the many identified VOCs, there are many others that can be grouped according to chemical class through their position on the chromatogram, but are not identified explicitly. Ten groups are shown in Fig. 4, with areas 1-8 representing branched and cyclic alkanes, area 9 representing unidentified monoterpenes and area 10 being the $\mathrm{C}_{4}$-substituted monoaro- matics species. The highly branched alkane species can be incorporated into the model by approximating the reactivity to be the same as for the straight-chain alkane equivalent. For example, for an unidentified branched alkane which contains six carbon atoms, it has been estimated that it would have the same reactivity with respect to $\mathrm{OH}$ as $n$-hexane (and the same, subsequent degradation mechanism). For unidentified monoterpenes, a reaction rate coefficient (and the subsequent degradation mechanism) the same as that for the reaction between $\mathrm{OH}$ and $\alpha$-pinene is assumed, whilst for unidentified substituted aromatics, the reaction rate coefficient with respect to $\mathrm{OH}$ (and degradation mechanism) is taken to be the same as that for propylbenzene. Inclusion of this additional reactive carbon in the model leads to a $0.4 \mathrm{~s}^{-1}$ increase in the alkane contribution and only a small increase of $\sim 0.1 \mathrm{~s}^{-1}$ due to increasing the carbon in the biogenic and aromatic classes combined. Despite the small contribution made by increasing the effective $\alpha$-pinene present, this increase in biogenic carbon leads to a further $1.1 \mathrm{~s}^{-1}$ increase in the contribution from model intermediates. Figure 5 compares the total modelled $\mathrm{OH}$ reactivity alongside the measured values when these additional unidentified species are included. Overall, this additional carbon (which is known to be present but cannot be fully identified) improves the overall model-tomeasured agreement with just $6 \%$ of the total reactivity now unaccounted for.

Considering the breakdown in modelled $\mathrm{OH}$ reactivity on a day by day basis (Fig. $1 \mathrm{~b}$ and c), the reactivity associated with the model intermediates deriving from the biogenic VOCs increases on the warmest days which were coincident with the easterly flows experienced at the beginning of the campaign (24-27 July). Di Carlo et al. (2004) found in a 


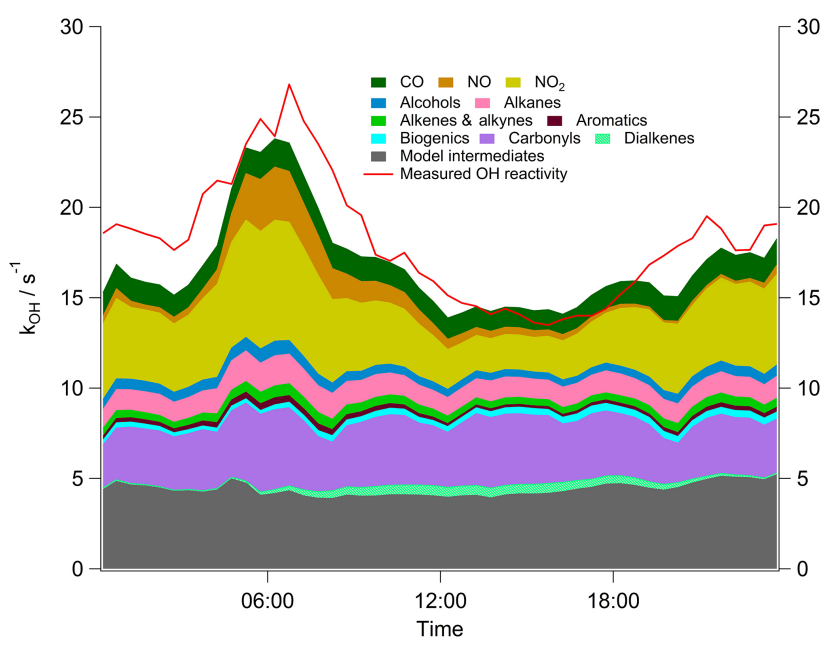

Figure 5. Average diurnal profile of measured reactivity and a breakdown of modelled reactivity into inorganic and organic classes when the model is constrained to the standard VOC suite measured by the dual-channel (DC)-GC-FID, the additional identified VOCs (including $\alpha$-pinene and limonene; see Table 1 for details) measured by $\mathrm{GC} \times \mathrm{GC}-\mathrm{FID}$ and the unassigned $\mathrm{GC} \times \mathrm{GC}$-FID peaks.

forested environment that missing reactivity increased with temperature, and hypothesised that unknown reactive biogenic VOCs, possibly unmeasured monoterpenes, accounted for this missing reactivity. They observed little difference between calculated reactivity and modelled reactivity, suggesting that the oxidation products of these biogenic species do not increase $\mathrm{OH}$ reactivity significantly. This finding is in contrast to the model predictions presented here and demonstrates that the higher levels of NO present in London relative to a forested environment promote more efficient model propagation and the generation of reactive model intermediates. Lower temperatures and, consequently, lower biogenic VOC concentrations, were observed (Fig. 1a) during the easterly flow experienced between 8 and 10 August relative to the first easterly period. The model predicts a lower reactivity from the model-generated intermediate species during this period despite $\left[\mathrm{NO}_{x}\right]$ being similar to those experienced during the first easterly period. On 9 and 10 August, during the second of the easterly flow periods captured, a model constrained only with the standard VOC measurements provided a reasonable estimate of the total observed reactivity (Fig. 1b). When the influence on the biogenic species is predicted to be the strongest, i.e. during the first easterly flow regime, only a model constrained to the extended VOC suite provides a reasonable estimate of the observed reactivity. From Fig. 1c it is evident that the largest fraction of missing reactivity occurs during the south-westerly flow conditions encountered between the 28 July and 5 August, and even considering the $1 \sigma$ uncertainty of the $\mathrm{OH}$ reactivity measurements of $\pm 3.2 \mathrm{~s}^{-1}$, the missing reactivity during this period is significant. The propensity of the model to underestimate re- activity during this south-westerly flow is further highlighted when the modelled averaged diurnal reactivity is taken for south-westerly and easterly conditions separately (Fig. 6). The contribution to the total reactivity made by any individual class of compounds does not change significantly between these two regimes; rather, all classes represent bigger $\mathrm{OH}$ sinks during the more polluted phase. The diurnal profile is much more distinct during the polluted phase, demonstrating a stronger traffic-based source, likely in combination with more significant boundary layer height changes over the course of the day during low wind speed periods. There is a very slight over-prediction during the easterly flow in $\mathrm{OH}$ reactivity during the afternoon and during the morning rushhour, but overall the agreement between model and measurements is excellent during the easterlies. In contrast, an underprediction in the observed $\mathrm{OH}$ reactivity throughout the day during south-westerly conditions is apparent, suggesting that either there are more undetected VOCs during south-westerly flows than during the easterly flows, or that the physical loss of the model-generated intermediates should be treated differently during these two contrasting air masses. The sensitivity of model predictions to the physical loss term of the model-generated intermediates is investigated in Sect. 3.2.

\subsection{Ability of the model to reconcile the observed formaldehyde concentration}

Thus far, all model runs have been constrained to the observed $\mathrm{HCHO}$ concentration. HCHO is formed during the oxidation of nearly every VOC and so may be considered a useful target species against which to assess atmospheric oxidation schemes. A model run constrained to (DC)-GC-FID VOCs only, but now unconstrained to $\mathrm{HCHO}$ significantly under-predicts (by $60 \%$ on average) the observed $\mathrm{HCHO}$ concentration (Fig. 7). The ability of the model to capture the observed HCHO in terms of magnitude is substantially improved (to within $32 \%$ of the observations) when the model is constrained to the extended VOC suite (including the contribution from the unidentified GC $\times$ GC-FID VOC species). This improved predicative capability of the model in terms of $\mathrm{HCHO}$ (as for $\mathrm{OH}$ reactivity) is almost entirely due to the inclusion of the biogenics. Even constrained to the extended VOC observations (and the unidentified GC $\times$ GC-FID VOC species), the model is unable to capture the HCHO concentration observed with the discrepancy greatest during the morning hours. This under-prediction may reflect inaccuracies in the physical deposition of HCHO in the model (discussed further in Sect. 3.2) but may also reflect a missing primary source of HCHO in the model. Similar findings are reported from field observations in the Po Valley in Italy, where the discrepancy between modelled and measured $\mathrm{OH}$ reactivity was found to be small, but $\mathrm{HCHO}$ concentrations were substantially under-predicted by a one-dimensional model, demonstrating an unidentified non-photochemical groundlevel source of HCHO (Kaiser et al., 2015). The unidentified 


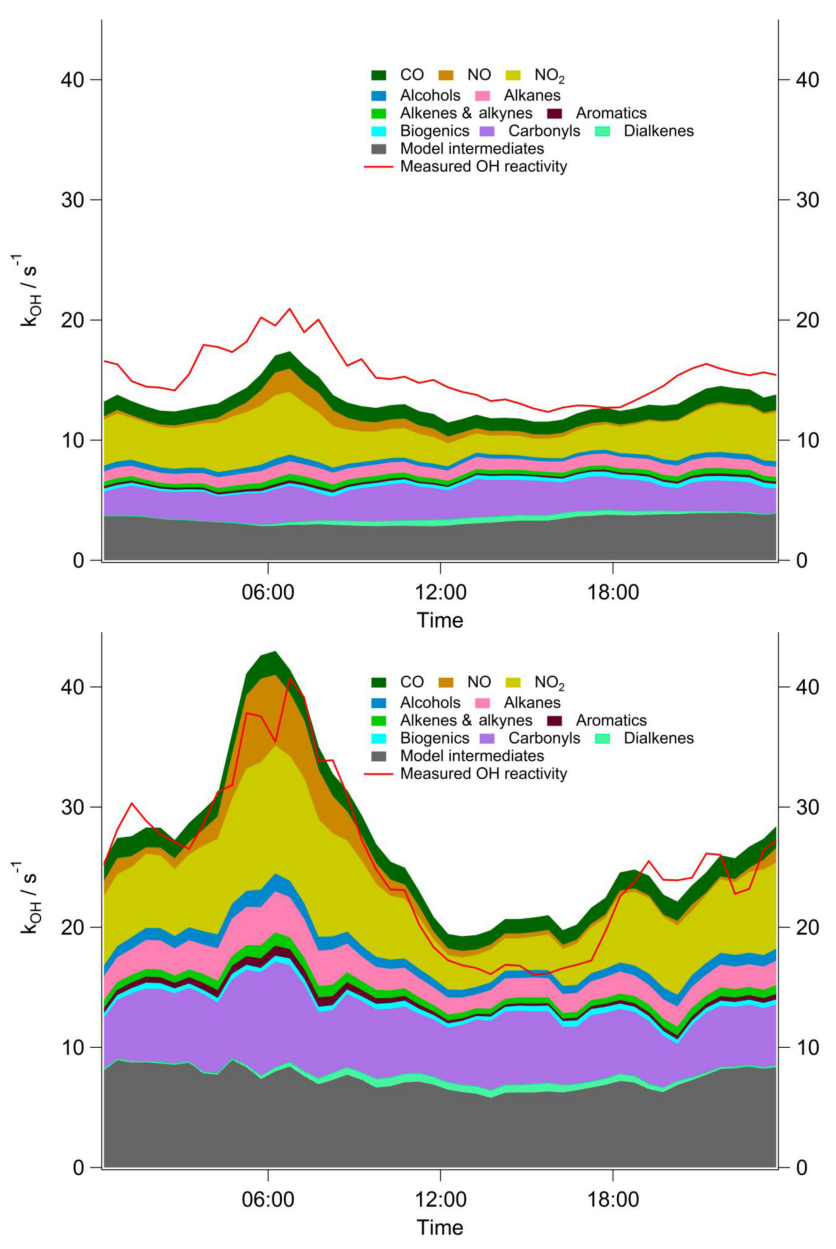

Figure 6. Average diurnal profile of measured reactivity and a breakdown of modelled reactivity into inorganic and organic classes when the model is constrained to the standard VOC suite measured by the dual-channel (DC)-GC-FID, additional VOCs (including $\alpha$ pinene and limonene; see Table 1 for details) measured by $\mathrm{GC} \times \mathrm{GC}$ FID and unassigned GC $\times$ GC-FID peaks. Top: average diurnal during south-westerly flows and bottom: average diurnal during easterly flows.

source of HCHO in the Po Valley was postulated to be a direct emission from agricultural land. In London, the missing $\mathrm{HCHO}$ peaks at $\sim 08: 00$ and may reflect a missing source directly emitted from vehicular exhausts.

\subsection{Sensitivity of model-generated intermediates to parameterisation of the rate of physical loss}

There is considerable uncertainty associated with the concentration of model species which are generated by reaction in the model rather than constrained to observations. Model species can undergo gas-phase reactions, may be lost via wet or dry deposition (at different rates depending on the particular species), be taken up on aerosol surfaces, or if their

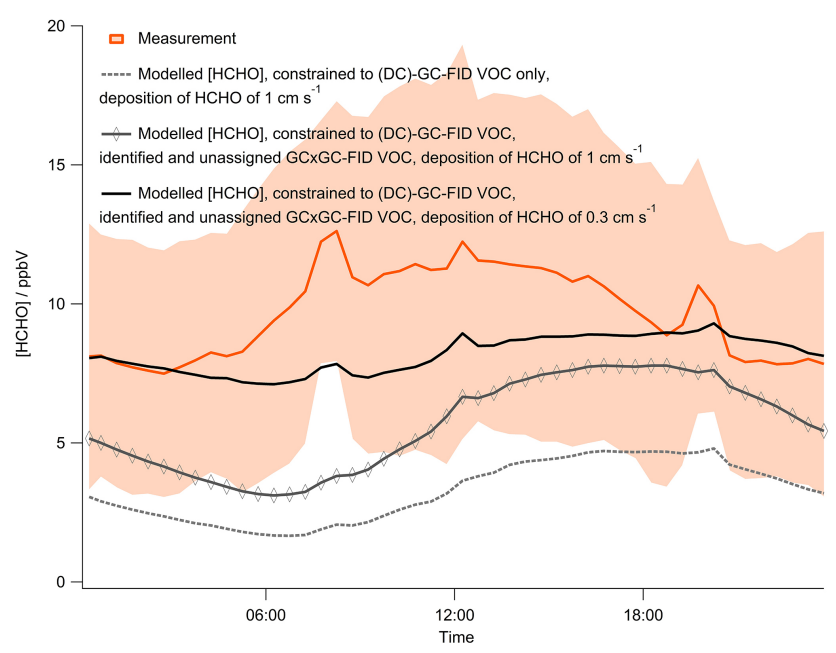

Figure 7. Average diurnal profile of the observed HCHO and modelled HCHO for different model scenarios (see text for further details). The shading represents the $1 \sigma$ variability of the measurements, with each data point representing $30 \mathrm{~min}$ averaged data.

lifetime is sufficiently long, there may be a net movement of these species either into or out of the model box.

In the model runs considered above, the deposition rate for all intermediate species (including $\mathrm{HCHO}$ in the model runs with $\mathrm{HCHO}$ unconstrained) was set equal to $1 \mathrm{~cm} \mathrm{~s}^{-1}$, which is equivalent to a lifetime of $\sim 27 \mathrm{~h}$ in a $1000 \mathrm{~m}$ boundary layer. The boundary layer varied from a minimum of $330 \mathrm{~m}$ at night to $1800 \mathrm{~m}$ in the afternoon. By treating the modelled physical loss as a function of boundary layer height, a dry deposition of species to the surface is reasonably well represented, but this method does not represent possible ventilation from the model box very well (as wind speeds picked up during the afternoon hours for example). Setting the boundary layer height in the model to a constant $300 \mathrm{~m}$ throughout effectively enhances the physical loss rate of intermediates during the afternoon when the boundary layer was previously set higher. Figure 8 highlights that this does modestly improve the overall modelled agreement with observed reactivity during the afternoon hours, but the reduction in modelled reactivity is small. This demonstrates that although the treatment of physical loss remains a highly uncertain model parameter, the concentration of model intermediates and their impact on modelled reactivity is not particularly sensitive to this term, with large changes in the lifetime of the intermediates (from $\sim 50$ to $\sim 8 \mathrm{~h}$ during the afternoon) only leading to a reduction of $0.6 \mathrm{~s}^{-1}$ (or $4 \%$ ) in the modelled reactivity at 14:00. It should be noted that this enhanced physical loss of intermediates would lead to further disagreement between the modelled and measured $\mathrm{OH}$ reactivity during south-westerly flow.

For the model to better represent the observed HCHO concentrations, a reduction in the physical loss of this species is needed. Reducing the deposition rate from 1 to $0.3 \mathrm{~cm} \mathrm{~s}^{-1}$ 


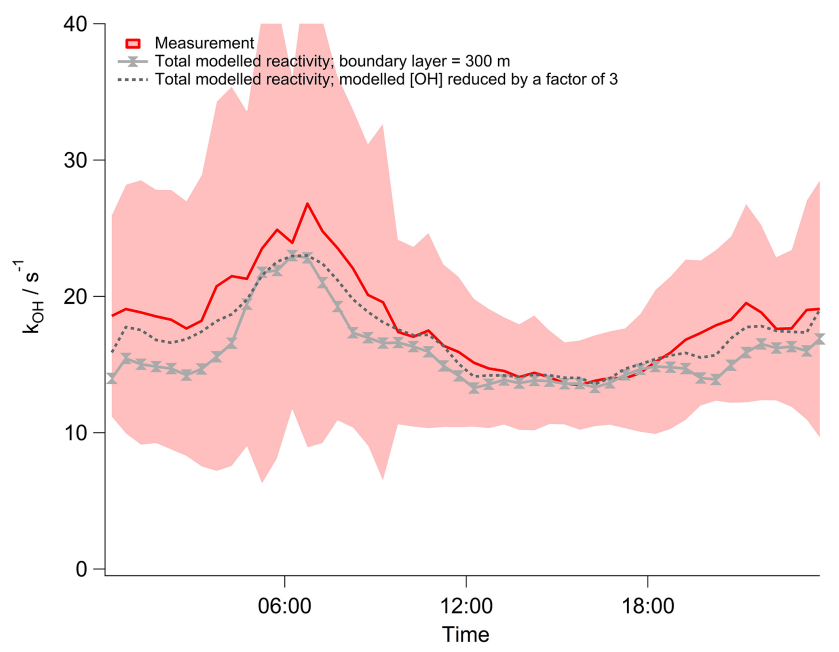

Figure 8. Average diurnal profile of the total modelled and measured $\mathrm{OH}$ reactivity for different model scenarios (see text for further details); the level of agreement shown here can be compared to the model-measured agreement presented in Fig. 5. The shading represents the $1 \sigma$ variability of the measurements, with each data point representing $30 \mathrm{~min}$ averaged data.

in the model (Fig. 7) enhances the modelled HCHO, leading to an improved model representation of this species at night. The model still underestimates the concentration of $\mathrm{HCHO}$ during the day (total underestimate of $16 \%$ on average), which may reflect the uncertainty in the treatment of the physical loss of other model-generated intermediates which go on to form $\mathrm{HCHO}$ themselves, or may reflect the small underestimation of $\mathrm{OH}$ reactivity $(6 \%)$ which remains, or may reflect, a small direct emission of HCHO not accounted for by the model (as discussed above). Despite the small under-prediction of $\mathrm{HCHO}$ concentration, this analysis demonstrates that the majority of the HCHO observed (84\%) can be accounted for by considering the oxidative degradation of the VOCs detected in London's atmosphere, and the $\mathrm{HCHO}$ concentration will be significantly underestimated if the VOC model constraints under-represent the actual VOC composition (particularly, if the contribution of the biogenics is neglected).

\subsection{Impact of the different VOC constraints on modelled OH}

As may be expected, with an increase in the modelled $\mathrm{OH}$ reactivity moving from the model run with standard VOC constraints to a run with the extended VOC constraints, the $\mathrm{OH}$ concentration predicted by the model is concomitantly reduced by $41 \%$ (standard VOC suite to extended VOC suite including contribution from unassigned peaks). This analysis demonstrates that neglecting the contribution of the higher VOCs $\left(\geqslant \mathrm{C}_{9}\right)$ (particularly $\alpha$-pinene and limonene) and model-generated intermediates can impact a model's ability to predict the oxidising capacity accurately.

It is also worth considering the influence that modelled $\mathrm{OH}$ concentrations have upon the predicted $\mathrm{OH}$ reactivity. Lowering the modelled $\mathrm{OH}$ concentration by $\sim$ a factor of 3 reduces the modelled $\mathrm{OH}$ reactivity due to the competition which exists between the rate of $\mathrm{OH}$ initiated production of model-generated intermediates and physical loss of these species (Edwards et al., 2013). As shown in Fig. 8, despite these substantial reductions in modelled $\mathrm{OH}$ concentrations, the modelled $\mathrm{OH}$ reactivity is only reduced by $0.24 \mathrm{~s}^{-1}$ (or $2 \%$ ) at 14:00 (GMT). These results demonstrate that the modelled reactivity is not particularly sensitive to the $[\mathrm{OH}]$, perhaps as a result of $\mathrm{OH}$ influencing both the rate of production and loss of these intermediates (the latter by further reaction with $\mathrm{OH}$ ).

\section{Atmospheric implications and the influence on the rate of in situ ozone production}

The definition of total $\mathrm{OH}$ reactivity as defined by Eq. (1) may be expanded to break down the contribution of organic and inorganic reactions:

$$
\begin{aligned}
k_{\mathrm{OH}} & =\sum k_{\mathrm{OH}+\mathrm{VOC}}[\mathrm{VOC}]+k_{\mathrm{OH}+\mathrm{NO}_{2}}\left[\mathrm{NO}_{2}\right] \\
& +k_{\mathrm{OH}+\mathrm{NO}}[\mathrm{NO}]+k_{\mathrm{OH}+\mathrm{O}_{3}}\left[\mathrm{O}_{3}\right]+k_{\mathrm{OH}+\mathrm{CO}}[\mathrm{CO}] \\
& +k_{\mathrm{OH}+\mathrm{HCHO}}[\mathrm{HCHO}] .
\end{aligned}
$$

The reaction of $\mathrm{OH}$ with $\mathrm{NO}$ (to form $\mathrm{HONO}$ ) or $\mathrm{NO}_{2}$ (to form $\mathrm{HNO}_{3}$ ) may be viewed as either a temporary or permanent radical sink, respectively, dependent upon the lifetime of the reservoir species formed. In contrast, the reaction of $\mathrm{OH}$ with VOCs, $\mathrm{O}_{3}, \mathrm{CO}$ or $\mathrm{HCHO}$ is the rate-determining step producing peroxy radicals and, in the presence of NO, net ozone production via the production and subsequent photolysis of $\mathrm{NO}_{2}$.

Assuming the steady-state approximation, an expression can be determined for the concentration of $\mathrm{RO}_{2}$ radicals which derive from the reaction of $\mathrm{OH}$ with VOC from a measurement of the total $\mathrm{OH}$ reactivity (with the contribution of inorganic reactions and any $\mathrm{HO}_{2}$ formation reactions subtracted), an $[\mathrm{OH}]$ measurement and an $\mathrm{RO}_{2}$ sink term represented as the average rate coefficient for reaction of $\mathrm{RO}_{2}$ with NO (under the conditions in London, other loss routes for $\mathrm{RO}_{2}$ are ignored):

$$
\begin{aligned}
& {\left[\mathrm{RO}_{2}\right]_{\mathrm{ss}}=} \\
& \frac{\left(k_{\mathrm{OH}}-\left(k_{\mathrm{OH}+\mathrm{NO}_{2}}\left[\mathrm{NO}_{2}\right]+k_{\mathrm{OH}+\mathrm{NO}}[\mathrm{NO}]+k_{\mathrm{OH}+\mathrm{O}_{3}}\left[\mathrm{O}_{3}\right]\right.\right.}{\left.+k_{\mathrm{OH}+\mathrm{CO}}[\mathrm{CO}]+k_{\mathrm{OH}+\mathrm{HCHO}}[\mathrm{HCHO}]\right)[\mathrm{OH}]} \\
& k_{\mathrm{RO}_{2}+\mathrm{NO}}[\mathrm{NO}]
\end{aligned}
$$

The rate of in situ ozone production resulting from $\left[\mathrm{RO}_{2}\right]_{\mathrm{ss}}$ may then be estimated using the following equation:

$$
P\left(\mathrm{O}_{3}\right)=k_{\mathrm{RO}_{2}+\mathrm{NO}}\left[\mathrm{RO}_{2}\right]_{\mathrm{ss}}[\mathrm{NO}]-k_{\mathrm{OH}+\mathrm{NO}_{2}}[\mathrm{OH}]\left[\mathrm{NO}_{2}\right] \text {. }
$$


Equation (5) considers the production of $\mathrm{NO}_{2}$ (and upon photolysis, $\mathrm{O}_{3}$ ) by reaction of $\mathrm{RO}_{2}$ radicals with $\mathrm{NO}$ only (ignoring $\mathrm{HO}_{2}$ ). The loss of $\mathrm{NO}_{2}$ by reaction, for example with $\mathrm{OH}$, rather than photolysis which generates $\mathrm{O}_{3}$, must also be taken into account when determining net production.

Using this methodology, an $\left[\mathrm{RO}_{2}\right]_{\mathrm{ss}}$ diurnal profile peaking at $\sim 6 \times 10^{7}$ molecule $\mathrm{cm}^{-3}$ is derived from total $\mathrm{OH}$ reactivity. From this $\left[\mathrm{RO}_{2}\right]_{\mathrm{ss}}$, an average in situ ozone production during the day (from $\mathrm{RO}_{2}+\mathrm{NO}$ ) of $\sim 22 \mathrm{ppbV} \mathrm{d}^{-1}$ is estimated. This analysis can be repeated using $k_{\mathrm{OH}}$ calculated from the standard VOC suite measured with the (DC)-GCFID alone (with the contribution from model intermediates and heavier weight VOCs omitted). The $\left[\mathrm{RO}_{2}\right]_{\mathrm{ss}}$ is reduced by $\sim 45 \%$, and consequently the calculated in situ $\mathrm{O}_{3}$ production from $\mathrm{RO}_{2}$ is reduced to $\sim 9 \mathrm{ppbV} \mathrm{d}^{-1}$.

Despite a number of approximations, this analysis suggests that in situ ozone predictions may be substantially underestimated if either oxidised VOC intermediate species are not considered or if the measured VOC suite does not sufficiently represent the actual primary VOC emissions.

\section{Conclusions}

The ability of the model to replicate the observed $\mathrm{OH}$ reactivity in London only when the reactivity of the extended suite of VOCs is considered demonstrates the role played by the heavier weight VOC fraction, particularly biogenics, in modifying the oxidising capacity of this megacity and the ability of these VOCs to drive up local ozone production. In contrast to a number of urban $\mathrm{OH}$ reactivity comparisons reported from other cities (e.g. Ren et al., 2003; Di Carlo et al., 2004; Mao et al., 2010), the observed $\mathrm{OH}$ reactivity in London can only be reconciled by consideration of model-generated intermediates. We have demonstrated that the oxidation products of $\alpha$-pinene and limonene contribute most significantly to the reactivity of the model-generated intermediate class and so differences in the abundances of these monoterpenes in different cities may influence how well $\mathrm{OH}$ reactivity can be calculated from the measured primary emissions before model-derived species need to be considered also. Similar to London, in Tokyo, where monoterpenes have been observed, a $30 \%$ under-prediction of $\mathrm{OH}$ reactivity was reported when observations were compared to calculated $\mathrm{OH}$ reactivity only (Chatani et al., 2009).

During the ClearfLo study, ozone exceeded $60 \mathrm{ppbV}$ on several days during easterly conditions and peaked at $100 \mathrm{ppbV}$ during the afternoon of the 25 July. Future ozone abatement strategies will need to consider the role both anthropogenic and biogenic emissions play in contributing to ozone production, even for relatively temperate locations such as London.
Acknowledgements. This work was supported by the National Environment Research Council under grant NE/H003193/1, and we are also grateful to the National Centre for Atmospheric Science, which is funded by NERC, for ongoing support. R. E. Dunmore would like to thank NERC (NE/J500197/1) for PhD funding. We would like to thank all participants of ClearfLo for their help in supporting these measurements.

Edited by: D. Farmer

\section{References}

Atkinson, R., Baulch, D. L., Cox, R. A., Crowley, J. N., Hampson, R. F., Hynes, R. G., Jenkin, M. E., Rossi, M. J., and Troe, J.: Evaluated kinetic and photochemical data for atmospheric chemistry: Volume III - gas phase reactions of inorganic halogens, Atmos. Chem. Phys., 7, 981-1191, doi:10.5194/acp-7-981-2007, 2007.

Barlow, J. F., Dunbar, T. M., Nemitz, E. G., Wood, C. R., Gallagher, M. W., Davies, F., O'Connor, E., and Harrison, R. M.: Boundary layer dynamics over London, UK, as observed using Doppler lidar during REPARTEE-II, Atmos. Chem. Phys., 11, 2111-2125, doi:10.5194/acp-11-2111-2011, 2011.

Bigi, A. and Harrison, R. M.: Analysis of the air pollution climate at a central urban background site, Atmos. Environ., 44, 20042012, doi:10.1016/j.atmosenv.2010.02.028, 2010.

Bohnenstengel, S. I., Belcher, S. E., Aiken, A., Allan, J. D., Allen, G., Bacak, A., Bannan, T. J., Barlow, J. F., Beddows, D. C. S., Bloss, W. J., Booth, A. M., Chemel, C., Coceal, O., Di Marco, C. F., Dubey, M. K., Faloon, K. H., Fleming, Z. L., Furger, M., Gietl, J. K., Graves, R. R., Green, D. C., Grimmond, C. S. B., Halios, C. H., Hamilton, J. F., Harrison, R. M., Heal, M. R., Heard, D. E., Helfter, C., Herndon, S. C., Holmes, R. E., Hopkins, J. R., Jones, A. M., Kelly, F. J., Kotthaus, S., Langford, B., Lee, J. D., Leigh, R. J., Lewis, A. C., Lidster, R. T., LopezHilfiker, F. D., McQuaid, J. B., Mohr, C., Monks, P. S., Nemitz, E., Ng, N. L., Percival, C. J., Prévôt, A. S. H., Ricketts, H. M. A., Sokhi, R., Stone, D., Thornton, J. A., Tremper, A. H., Valach, A. C., Visser, S., Whalley, L. K., Williams, L. R., Xu, L., Young, D. E., and Zotter, P: Meteorology, air quality, and health in London: The ClearfLo project, B. Am. Meteorol. Soc., 96, 779-804, doi:10.1175/BAMS-D-12-00245.1, 2015.

Chatani, S., Shimo, N., Matsunaga, S., Kajii, Y., Kato, S., Nakashima, Y., Miyazaki, K., Ishii, K., and Ueno, H.: Sensitivity analyses of $\mathrm{OH}$ missing sinks over Tokyo metropolitan area in the summer of 2007, Atmos. Chem. Phys., 9, 8975-8986, doi:10.5194/acp-9-8975-2009, 2009.

Di Carlo, P., Brune, W. H., Martinez, M., Harder, H., Lesher, R., Ren, X. R., Thornberry, T., Carroll, M. A., Young, V., Shepson, P. B., Riemer, D., Apel, E., and Campbell, C.: Missing OH reactivity in a forest: Evidence for unknown reactive biogenic VOCs, Science, 304, 722-725, doi:10.1126/science.1094392, 2004.

Dolgorouky, C., Gros, V., Sarda-Esteve, R., Sinha, V., Williams, J., Marchand, N., Sauvage, S., Poulain, L., Sciare, J., and Bonsang, B.: Total OH reactivity measurements in Paris during the 2010 MEGAPOLI winter campaign, Atmos. Chem. Phys., 12, 95939612, doi:10.5194/acp-12-9593-2012, 2012.

Dunmore, R. E., Hopkins, J. R., Lidster, R. T., Lee, J. D., Evans, M. J., Rickard, A. R., Lewis, A. C., and Hamilton, J. F.: 
Diesel-related hydrocarbons can dominate gas phase reactive carbon in megacities, Atmos. Chem. Phys., 15, 9983-9996, doi:10.5194/acp-15-9983-2015, 2015.

Edwards, P. M., Evans, M. J., Furneaux, K. L., Hopkins, J., Ingham, T., Jones, C., Lee, J. D., Lewis, A. C., Moller, S. J., Stone, D., Whalley, L. K., and Heard, D. E.: OH reactivity in a South East Asian tropical rainforest during the Oxidant and Particle Photochemical Processes (OP3) project, Atmos. Chem. Phys., 13, 9497-9514, doi:10.5194/acp-13-9497-2013, 2013.

Goldstein, A. H. and Galbally, I. E.: Known and unexplored organic constituents in the earth's atmosphere, Environ. Sci. Technol., 41, 1514-1521, doi:10.1021/es072476p, 2007.

Ingham, T., Goddard, A., Whalley, L. K., Furneaux, K. L., Edwards, P. M., Seal, C. P., Self, D. E., Johnson, G. P., Read, K. A., Lee, J. D., and Heard, D. E.: A flow-tube based laser-induced fluorescence instrument to measure $\mathrm{OH}$ reactivity in the troposphere, Atmos. Meas. Tech., 2, 465-477, doi:10.5194/amt-2-465-2009, 2009.

Jenkin, M. E., Wyche, K. P., Evans, C. J., Carr, T., Monks, P. S., Alfarra, M. R., Barley, M. H., McFiggans, G. B., Young, J. C., and Rickard, A. R.: Development and chamber evaluation of the MCM v3.2 degradation scheme for $\beta$-caryophyllene, Atmos. Chem. Phys., 12, 5275-5308, doi:10.5194/acp-12-52752012, 2012.

Kaiser, J., Wolfe, G. M., Bohn, B., Broch, S., Fuchs, H., Ganzeveld, L. N., Gomm, S., Häseler, R., Hofzumahaus, A., Holland, F., Jäger, J., Li, X., Lohse, I., Lu, K., Prévôt, A. S. H., Rohrer, F., Wegener, R., Wolf, R., Mentel, T. F., Kiendler-Scharr, A., Wahner, A., and Keutsch, F. N.: Evidence for an unidentified non-photochemical ground-level source of formaldehyde in the Po Valley with potential implications for ozone production, Atmos. Chem. Phys., 15, 1289-1298, doi:10.5194/acp-15-12892015, 2015.

Kovacs, T. A. and Brune, W. H.: Total OH loss rate measurement, J. Atmos. Chem., 39, 105-122, doi:10.1023/a:1010614113786, 2001.

Kovacs, T. A., Brune, W. H., Harder, H., Martinez, M., Simpas, J. B., Frost, G. J., Williams, E., Jobson, T., Stroud, C., Young, V., Fried, A., and Wert, B.: Direct measurements of urban OH reactivity during Nashville SOS in summer 1999, J. Environ. Monit., 5, 68-74, doi:10.1039/b204339d, 2003.

Lou, S., Holland, F., Rohrer, F., Lu, K., Bohn, B., Brauers, T., Chang, C.C., Fuchs, H., Häseler, R., Kita, K., Kondo, Y., Li, X., Shao, M., Zeng, L., Wahner, A., Zhang, Y., Wang, W., and Hofzumahaus, A.: Atmospheric $\mathrm{OH}$ reactivities in the Pearl River Delta - China in summer 2006: measurement and model results, Atmos. Chem. Phys., 10, 11243-11260, doi:10.5194/acp-10-11243-2010, 2010.

Mao, J., Ren, X., Chen, S., Brune, W. H., Chen, Z., Martinez, M., Harder, H., Lefer, B., Rappenglueck, B., Flynn, J., and Leuchner, M.: Atmospheric oxidation capacity in the summer of Houston 2006: Comparison with summer measurements in other metropolitan studies, Atmos. Environ., 44, 4107-4115, doi:10.1016/j.atmosenv.2009.01.013, 2010.
MCM: Master Chemical Mechanism, Version 3.2, http://mcm. leeds.ac.uk/MCM/, 2016.

Ren, X., Brune, W. H., Oliger, A., Metcalf, A. R., Simpas, J. B., Shirley, T., Schwab, J. J., Bai, C., Roychowdhury, U., Li, Y., Cai, C., Demerjian, K. L., He, Y., Zhou, X., Gao, H., and Hou, J.: $\mathrm{OH}, \mathrm{HO}_{2}$, and $\mathrm{OH}$ reactivity during the PMTACS-NY Whiteface Mountain 2002 campaign: Observations and model comparison, J. Geophys. Res.-Atmos., 111, doi:10.1029/2005jd006126, 2006.

Ren, X. R., Harder, H., Martinez, M., Lesher, R. L., Oliger, A., Shirley, T., Adams, J., Simpas, J. B., and Brune, W. H.: $\mathrm{HO}_{x}$ concentrations and $\mathrm{OH}$ reactivity observations in New York City during PMTACS-NY2001, Atmos. Environ., 37, 3627-3637, doi:10.1016/s1352-2310(03)00460-6, 2003.

Sadanaga, Y., Yoshino, A., Watanabe, K., Yoshioka, A., Wakazono, Y., Kanaya, Y., and Kajii, Y.: Development of a measurement system of $\mathrm{OH}$ reactivity in the atmosphere by using a laserinduced pump and probe technique, Review of Scientific Instruments, 75, 2648-2655, doi:10.1063/1.1775311, 2004.

Sadanaga, Y., Yoshino, A., Kato, S., and Kajii, Y.: Measurements of $\mathrm{OH}$ reactivity and photochemical ozone production in the urban atmosphere, Environ. Sci. Technol., 39, 8847-8852, doi:10.1021/es049457p, 2005.

Shirley, T. R., Brune, W. H., Ren, X., Mao, J., Lesher, R., Cardenas, B., Volkamer, R., Molina, L. T., Molina, M. J., Lamb, B., Velasco, E., Jobson, T., and Alexander, M.: Atmospheric oxidation in the Mexico City Metropolitan Area (MCMA) during April 2003, Atmos. Chem. Phys., 6, 2753-2765, doi:10.5194/acp-62753-2006, 2006.

Sinha, V., Williams, J., Crowley, J. N., and Lelieveld, J.: The Comparative Reactivity Method - a new tool to measure total $\mathrm{OH}$ Reactivity in ambient air, Atmos. Chem. Phys., 8, 2213-2227, doi:10.5194/acp-8-2213-2008, 2008.

Stone, D., Whalley, L. K., Ingham, T., Edwards, P. M., Cryer, D. R., Brumby, C. A., Seakins, P. W., and Heard, D. E.: Measurement of $\mathrm{OH}$ reactivity by laser flash photolysis coupled with laserinduced fluorescence spectroscopy, Atmos. Meas. Tech. Discuss., submitted, 2016.

Whalley, L. K., Edwards, P. M., Furneaux, K. L., Goddard, A., Ingham, T., Evans, M. J., Stone, D., Hopkins, J. R., Jones, C. E., Karunaharan, A., Lee, J. D., Lewis, A. C., Monks, P. S., Moller, S. J., and Heard, D. E.: Quantifying the magnitude of a missing hydroxyl radical source in a tropical rainforest, Atmos. Chem. Phys., 11, 7223-7233, doi:10.5194/acp-11-7223-2011, 2011.

Yoshino, A., Sadanaga, Y., Watanabe, K., Kato, S., Miyakawa, Y., Matsumoto, J., and Kajii, Y.: Measurement of total $\mathrm{OH}$ reactivity by laser-induced pump and probe technique - comprehensive observations in the urban atmosphere of Tokyo, Atmos. Environ., 40, 7869-7881, doi:10.1016/j.atmosenv.2006.07.023, 2006.

Yoshino, A., Nakashima, Y., Miyazaki, K., Kato, S., Suthawaree, J., Shimo, N., Matsunaga, S., Chatani, S., Apel, E., Greenberg, J., Guenther, A., Ueno, H., Sasaki, H., Hoshi, J., Yokota, H., Ishii, K., and Kajii, Y.: Air quality diagnosis from comprehensive observations of total $\mathrm{OH}$ reactivity and reactive trace species in urban central Tokyo, Atmos. Environ., 49, 51-59, doi:10.1016/j.atmosenv.2011.12.029, 2012. 